\title{
DISTRIBUSI DAN KERAPATAN EDELWEIS (Anaphalis javanica) DIGUNUNG BATOK TAMAN NASIONAL BROMO TENGGER SEMERU
}

\author{
DIDIK WAHYUDI
}

\begin{abstract}
ABSTRAK
Gunung Batok merupakan satu diantara gunung-gunung di Taman Nasional Bromo Tengger Semeru yang merupakan habitat edelweis (Anaphalis Javanica). Keberadaan edelweis di gunung batok pada beberapa tahun terakhir mulai terancam kelestariannya karena kebakaran dan perambahan oleh warga sekitar dan wisatawan. Berdasarkan hal tersebut maka perlu dilakukan penelitian tentang distribusi dan kepadatan edelweis (A. javanica) di Gunung Batok Taman Nasional Bromo Tengger Semeru dengan tujuan untuk mengetahui pola penyebaran dan kerapatan edelweis (A. javanica) di Gunung Batok Taman Nasional Bromo Tengger Semeru.

Penelitian ini bertujuan untuk mengetahui kerapatan edelweis (A.javanica) dan distribusinya serta faktor lingkungan apa yang paling mempengaruhi terhadap kelimpahan edelweis (A. javanica). Penelitian ini dilaksanakan di Gunung Batok Taman Nasional Bromo Tengger semeru pada bulan April sampai dengan September 2010. Penelitian bersifat deskriptif kuantitatif. Pengambilan sampel dilakukan dengan membagi Gunung Batok menjadi 4 stasiun berdasarkan arah mata angin. Setiap stasiun dipasang transek dengan panjang $50 \mathrm{~m}$ sebanyak 10 transek. Faktor lingkungan yang diamati meliputi kelembaban, suhu, dan kecepatan angin. Data kerapatan dianalisis dengan rumus jumlah edelweis/luasarea, pola distribusi edelweis dianalisis dengan menggunakan Indeks Morisita dengan uji Chi-square dan hubungan factor lingkungan dan kelimpahan edelweis (A. javanica) dianalisis dengan regresi ganda. Setiap edelweis (A. javanica) yang ditemui ditandai titik koordinatnya dengan GPS, kemudian untuk mengetahui posisi edelweis di Gunung Batok

Taman Nasional Bromo tengger Semeru data diolah menggunakan google earth. Hasil penelitian menemukan 115, edelweis/ha. Berdasarkan analisis Indeks Morisita menunjukkan bahwa pola penyebaran edelweis (A. javanica) cenderung mengelompok dan setelah di uji lanjut dengan uji chi-squere diketahui bahwa distribusinya seragam. Seтиa variabel independen (suhu, kelembaban dan kecepatan angin) tidak mempunyai korelasi yang erat terhadap variabel bebas (kepadatan Edelweis (A. javanica)) di Gunung Batok Taman Nasional Bromo Tengger Semeru
\end{abstract}

Kata kunci : Distribusi, Kerapatan, Edelweis (Anaphalis javanica), Gunung Batok

\section{PENDAHULUAN}

Indonesia merupakan negara yang mempunyai keanekaragaman hayati yang sangat besar. Keanekaragaman hayati yang sangat tinggi ini merupakan suatu koleksi yang unik dan mempunyai potensi genetik yang besar (Nurma, 2009). Besarnya keanekaragaman tersebut dikarenakan oleh letak wilayah Negara Indonesia yang berada di daerah tropis dengan kondisi iklim yang sedemikian rupa, sehingga memungkinkan bagi segala macam tumbuhan dan hewan dapat hidup dan berkembang biak. Salah satu kekayaan alam dan keanekaragaman hayati terdapat di hutan, terutama dikawasan hutan alam dimana setiap individu pohon dan populasi penyusunnya memiliki variasi yang sangat besar menurut sifat genetik dan lingkungannya, sehingga tidak ada flora maupun fauna memiliki ciriciri yang sama meskipun termasuk dalam satu jenis (Mifta, 2005)

Hutan hujan tropis di Pulau Jawa yang merupakan gudang keanekaragaman hayati telah mengalami kerusakan yang meluas sehingga sebagian besar hutan tersisa sekarang terkonsentrasi pada wilayah pegunungan dengan lereng-lerengnya yang terjal (Whitten et al., 1996). Mengingat fungsi ekologisnya yang sangat besar maka hampir seluruh gunung-gunung berhutan ini telah ditetapkan sebagai daerah yang dilindungi baik dalam status kawasan pelestarian alam, suaka alam maupun hutan lindung.

Satu diantara pegunungan yang digunakan sebagai tempat konservasi sekaligus Taman Nasional adalah Taman Nasional Bromo Tengger Semeru (TNBTS). Menurut Hidayat, (2007) rentang ketinggian taman Nasional Bromo

Tengger adalah antara $750-3676 \mathrm{~m}$ di atas permukaan laut. Rentang ketinggian yang begitu lebar ini memungkinkan kawasan konservasi tersebut memiliki keragaman hayati yang cukup tinggi dengan karakter vegetasi yang khas dataran tinggi basah seperti edelweis (Anaphalis javanica), cemara gunung (Casuarina junghuhniana) dan adas (Foeniculum vulgare). 
Salah satu tumbuhan khas yang terdapat di TNBTS dan dalam status dilindungi adalah edelweis (Anaphalis javanica). Edelweis mempunyai manfaat ekologis yang nilainya sukar diukur dengan uang. Bunganya merupakan sumber makanan bagi serangga-serangga tertentu. Van Leeuwen (1933), dalam Aliadi (1990) mengemukakan bahwa terdapat \pm 300 species serangga yang berasal dari ordo Hemiptera, Thysanoptera, Lepidoptera, Diptera dan Hymenoptera, yang ditemui pada bunga edelweis. Kulit batangnya bercelah dan mengandung banyak air, sehingga dapat menjadi tempat hidup bagi beberapa jenis lumut dan lichen, seperti Cladinia calycantha, Cetraria sanguinea, dan sebagainya (Van Leeuwen, 1933). Demikian pula dengan akarnya yang muncul di permukaan tanah, merupakan tempat hidup cendawan tertentu membentuk mikoriza. Cendawancendawan tersebut mendapat oksigen dan tempat hidup, sedang edelweiss mendapat unsur hara dari cendawan (Van Faber, 1927 dalam Van Leeuwen, 1933). Itulah sebabnya edelweis dapat hidup di tanah yang miskin hara.

Informasi ilmiah tentang penyebaran dan kerapatan A. javanica di Gunung Batok Taman Nasional Bromo Tengger Semeru belum banyak terungkap, sementara itu pengambilan secara ilegal oleh pengunjung dan kebakaran terjadi tiap tahunnya. Oleh karena itu penelitian tentang distribusi penyebaran dan kerapatan edelweis di Gunung Batok TNBTS serta pemetaan letak tanaman tersebut perlu dilakukan untuk mengetahui potensi sumber dayanya

\section{METODE PENELITIAN}

Penelitian ini menggunakan metode deskriptif kuantitatif yang mendiskripsikan tentang pola sebaran, kerapatan edelweis (Anaphalis javanica) serta faktor-faktor lingkungan yang mempengaruhi jumlah edelweis (A. javanica).

\section{Alat dan bahan}

Alat dan bahan yang digunakan dalam penelitian ini adalah Kompas, Pita meteran atau roll, Global Positioning Sytem (GPS) merk GPSmap 276C, Hygro- Thermometer merk Extech Instrument Type 407445A, kamera merk canon 10MP Type A480, tali rafia, peta dasar Taman Nasional Bromo Tengger Semeru, alat tulis menulis dan obyek kawasan hutan Taman Nasional Bromo Tengger.

\section{Prosedur Penelitian}

Penelitian ini menggunakan metode transek sabuk (Belt transect). Transek adalah jalur sempit melintang pada lahan yang akan dipelajari atau diselidiki (Fachrul, 2006). Panjang transek yang digunakan adalah $50 \mathrm{~m}$. Sepanjang garis transek dipasang plot ukuran $2 \times 2 \mathrm{~m}$ sedangkan jumlah transek yang digunakan dalam penelitian ini adalah $10 \%$ dari luas wilayah yang akan diteliti

Metode yang digunakan agar pengambilan sampel bisa merata adalah dengan membagi Gunung Batok menjadi 4 stasiun pengamatan berdasarkan pada arah mata angin yaitu bagian barat, timur, utara dan selatan. Setiap stasiun pengamatan dibagi menjadi 2 titik pengamatan berdasarkan derajat arah mata angin (gambar 3.2). Pada masing-masing titik pengamatan diletakkan garis transek sepanjang $50 \mathrm{~m}$ sebanyak 5 garis transek.

Setiap Bunga Edelweis yang ditemui dalam transek di tentukan titik koordinatnya menggunakan GPS (lampiran 6), kemudian data diolah dengan menggunakan Google Earth agar diketahui letak edelweis dalam peta.

\section{Analisis Data \\ Kerapatan}

Kerapatan merupakan total jumlah individu yang ditemukan selama pengamatan. Indeks Kerapatan memberikan gambaran suatu komposisi jenis dalam komunitas (Fachrul, 2007). Untuk mengetahui kerapatan Edelweis (A.javanica) dipergunakan rumus sebagai berikut:

$\mathrm{Pi}=\frac{\sum \text { Edelwis }}{\text { Luas area }}$

Indeks Penyebaran Morisita

Indeks Penyebaran Morisita dapat dihitung dengan menggunakan rumus:

$I d=n \frac{\sum X^{2}-N}{N(N-1)}$

Penentuan Posisi Edelweis (A. javanica) dalam peta Penentuan letak Edelweis (A. javanica) dalam peta menggunakan progam google earth. Setiap Edelweis (A. javanica) yang ditemui dalam setiap transek di tandai dengan menggunakan Global Positioning System (GPS). Titik-titik koordinat tersebut (lampiran 6), dimasukkan dalam progam google earth sehingga diketahui posisi keberadaan Edelweis (A. javanica) di Gunung Batok Taman Nasional Bromo Tengger Semeru

\section{Faktor Lingkungan Abiotik}


Faktor lingkungan Abiotik yang paling menentukan terhadap jumlah A. javanica dianalisis dengan Analisis Regresi Ganda.

\section{HASIL DAN PEMBAHASAN}

\section{Kerapatan Edelweis (A. javanica)}

Tabel 4.1 Kerapatan edelweis (A. javanica) pada berbagai arah di Gunung BatokTNBTS

\begin{tabular}{|l|l|l|l|}
\hline No & Arah Mata Angin & Jumlah & $\begin{array}{l}\text { Kerapatan (Jumlah } \\
\text { edelweis/ha ) }\end{array}$ \\
\hline 1 & Utara & 578 & 722,5 \\
\hline 2 & Selatan & 0 & 0 \\
\hline 3 & Barat & 126 & 157,5 \\
\hline 4 & Timur & 45 & 56,25 \\
\hline
\end{tabular}

Berdasarkan tabel 4.1 menunjukkan bahwa hasil penghitungan kerapatan edelweis (A. javanica) menggunakan rumus (Kerapatan = jumlah edelweis/luas area) didapatkan nilai kerapatan edelweis (A. javanica) daerah Utara (722,5 edelweis/ha), daerah Selatan (0), daerah Barat (157,5 edelweis/ha) dan daerah Timur (56,25 edelweis/ha). Hal ini menunjukkan bahwa kerapatan Tertinggi terletak di daerah Utara, disusul kemudian daerah Barat dan Timur. Sedangkan kerapatan terendah terletak di daerah Selatan yaitu 0 edelweis/ha

\section{Pembahasan}

Kerapatan edelweis (A. javanica) di Gunung Batok yang tertinggi terdapat di daerah Utara dengan nilai sebesar 722,5 edelweis/ha (tabel 4.1). Di daerah Utara, edelweis (A. javanica) paling banyak ditemukan di transek 9 yaitu 116 edelweis (lampiran 1). Edelweis paling sedikit ditemukan di transek 1 yaitu 22 edelweis. Setiap transek di bagian Utara berisi edelweis (A. javanica) lebih dari 20 per transeknya (gambar 4.1 ). Pada gambar 4.1, edelweis (A. javanica) banyak ditemukan di daerah terbuka dan pada lereng-lereng gunung dan menurut Aliadi (1990) habitat edelweis (A. javanica) adalah daerah lereng-lereng dengan topografi datar dan Van steenis (1933) dalam Aliadi (1990) mengemukakan bahwa edelweis (A. javanica) dapat tumbuh pada daerah perbatasan antara hutan dan daerah terbuka, karena kebutuhan yang paling penting dari tumbuhan ini adalah cahaya.

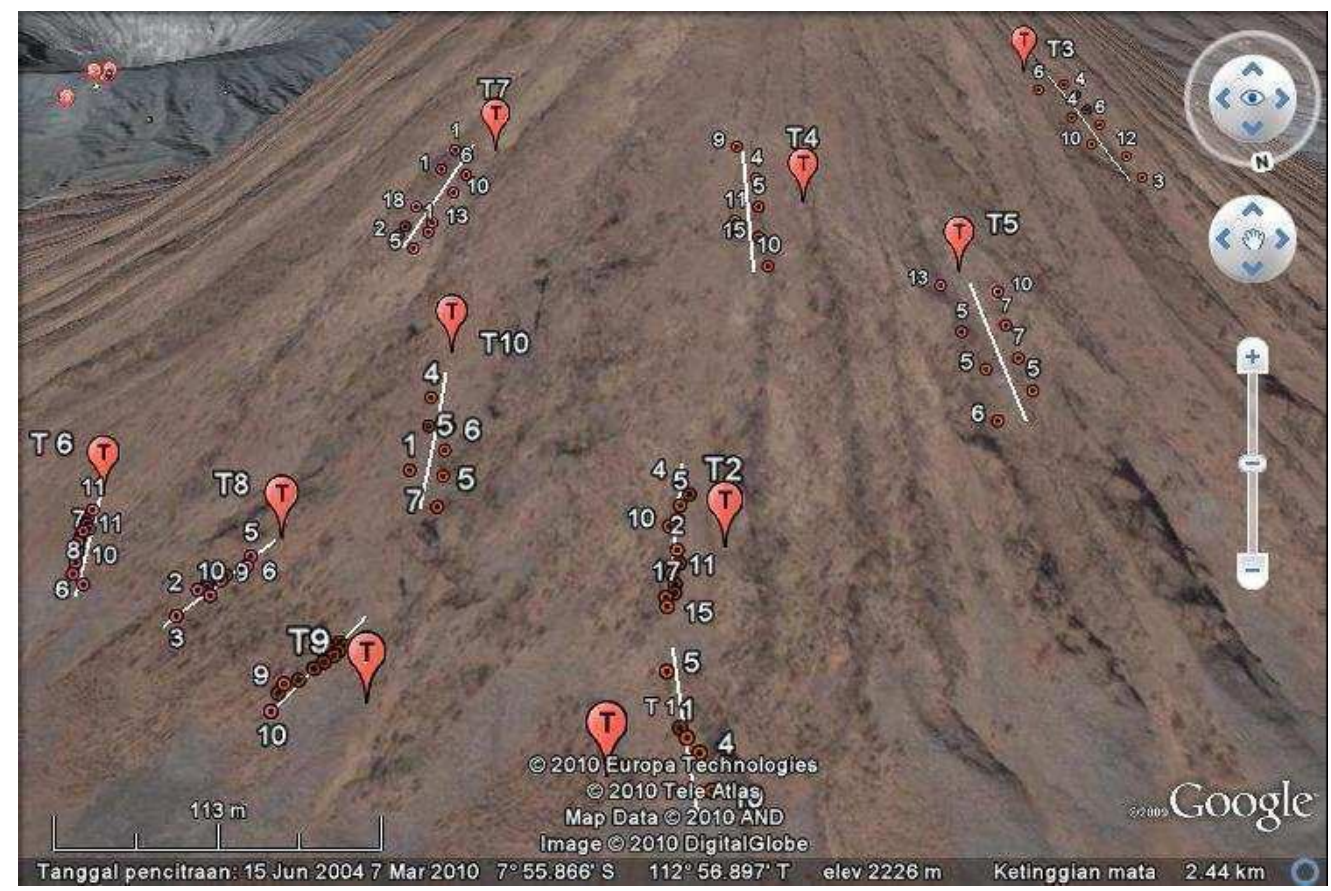

Gambar 4.1 Letak edelweis (A. javanica) di Gunung Batok bagian Utara (Google earth, 2010) 


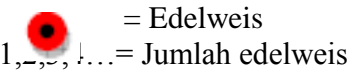

Edelweis (A. javanica) banyak ditemukan dibagian Utara disebabkan karena bagian Utara Gunung Batok merupakan daerah yang paling subur bila dibandingkan dengan bagian Selatan, Timur dan Barat. Hal ini dibuktikan dengan tumbuhnya beberapa tumbuhan seperti cemara gunung (Casuarina junghuhniana), pinus (pinus merkusii), petai cina, ilalang, dan paku-pakuan (gambar 4.2). Tumbuhnya bermacam-macam tumbuhan ini menunjukkan bahwa bagian Utara Gunung Batok mempunyai faktor abiotik yang sesuai untuk hidup. Menurut Indriyanto (2007), kemampuan tumbuhan untuk hidup dan bereproduksi tergantung kepada faktor biotik dan banyak faktor abiotik, dan salah satu diantara faktor tersebut merupakan faktor pembatas yang sangat penting. Edelweis (A. javanica) banyak ditemukan di bagian Utara Gunung Batok disebabkan juga karena bagian Utara gunung batok merupakan daerah yang aman dari asap yang mengandung sulfur yang dihasilkan oleh kawah Gunung Bromo sehingga keanekaragaman spesies di daerah ini lebih tinggi bila dibandingkan dengan bagian Selatan, Barat dan Timur.

Kerapatan edelweis (A. javanica) di bagian Selatan Gunung Bromo adalah edelweis/ha. Gambar 4.3 menunjukkan bahwa dari 10 transek yang diletakkan di bagian selatan tidak ditemukan edelweis sama sekali. Hal ini disebabkan karena daerah Selatan Gunung Batok merupakan daerah kering berbatu sehingga sedikit sekali tumbuhan yang bisa hidup di daerah Selatan (gambar 4.4). Tumbuhan yang bisa hidup di daerah selatan adalah ilalang (Imperata cylindrica), tapi ilalang pun hanya ditemukan pada daerah sekitar puncak Gunung Batok, sedangkan pada daerah yang menghadap dengan kawah Gunung Bromo (kaki Gunung Batok bagian Selatan) tidak ditemukan tumbuhan sama sekali. Hal ini disebabkan karena kawah Gunung Bromo yang aktif mengeluarkan asap yang menghasilkan sulfur, sehingga kebanyakan tumbuhan yang hidup disana mati karena kering.

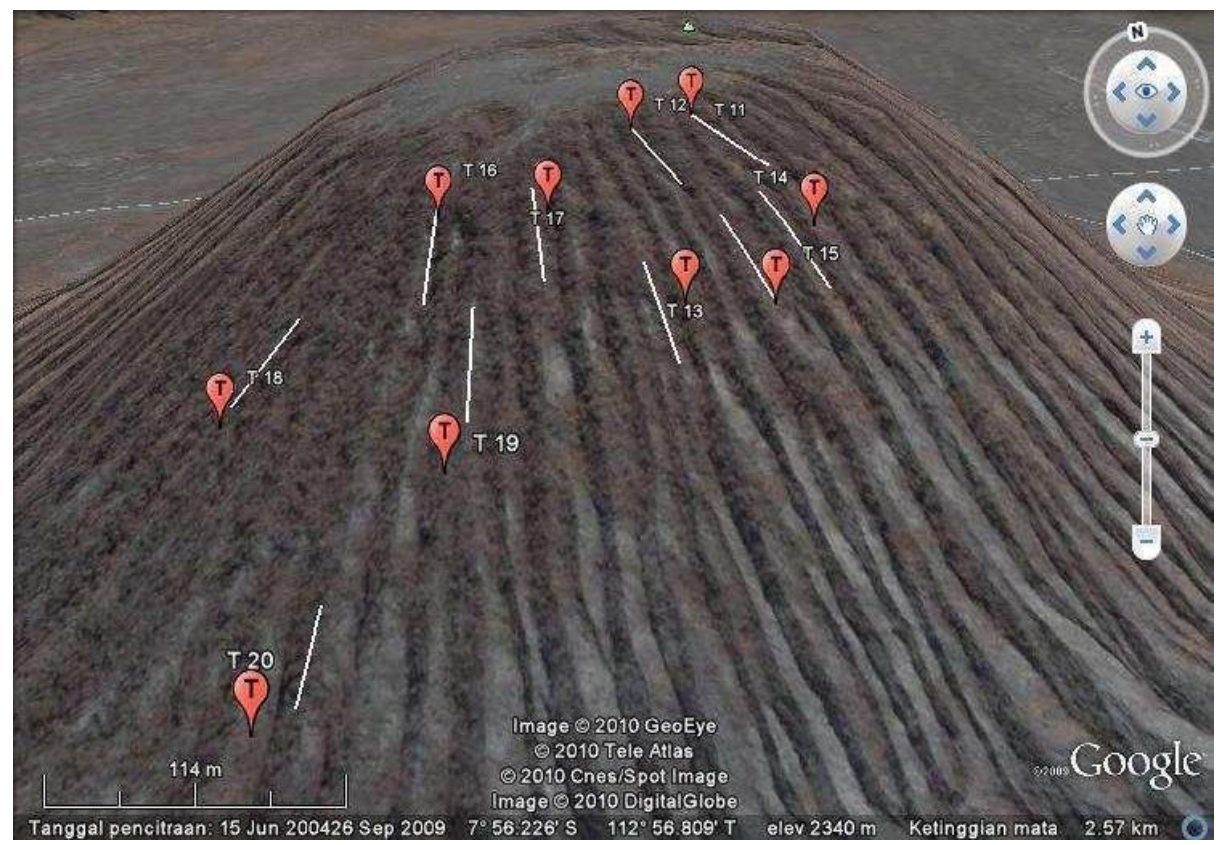

Gambar 4.3 Posisi transek di Gunung Batok bagian Selatan (Google earth, 2010)

Kerapatan edelweis (A. javanica) di Gunung Batok bagian Barat adalah 157,5 edelweis/ha. Di Gunung Batok bagian Barat, edelweis (A. javanica) banyak ditemukan di transek 28 dan 30 yaitu 35 edelweis dan 32 edelweis dan pada transek 24 dan 25 tidak ditemukan edelweis sama sekali. Selain itu edelweis lebih banyak ditemukan di bagian Barat daya (gambar 4.3) 


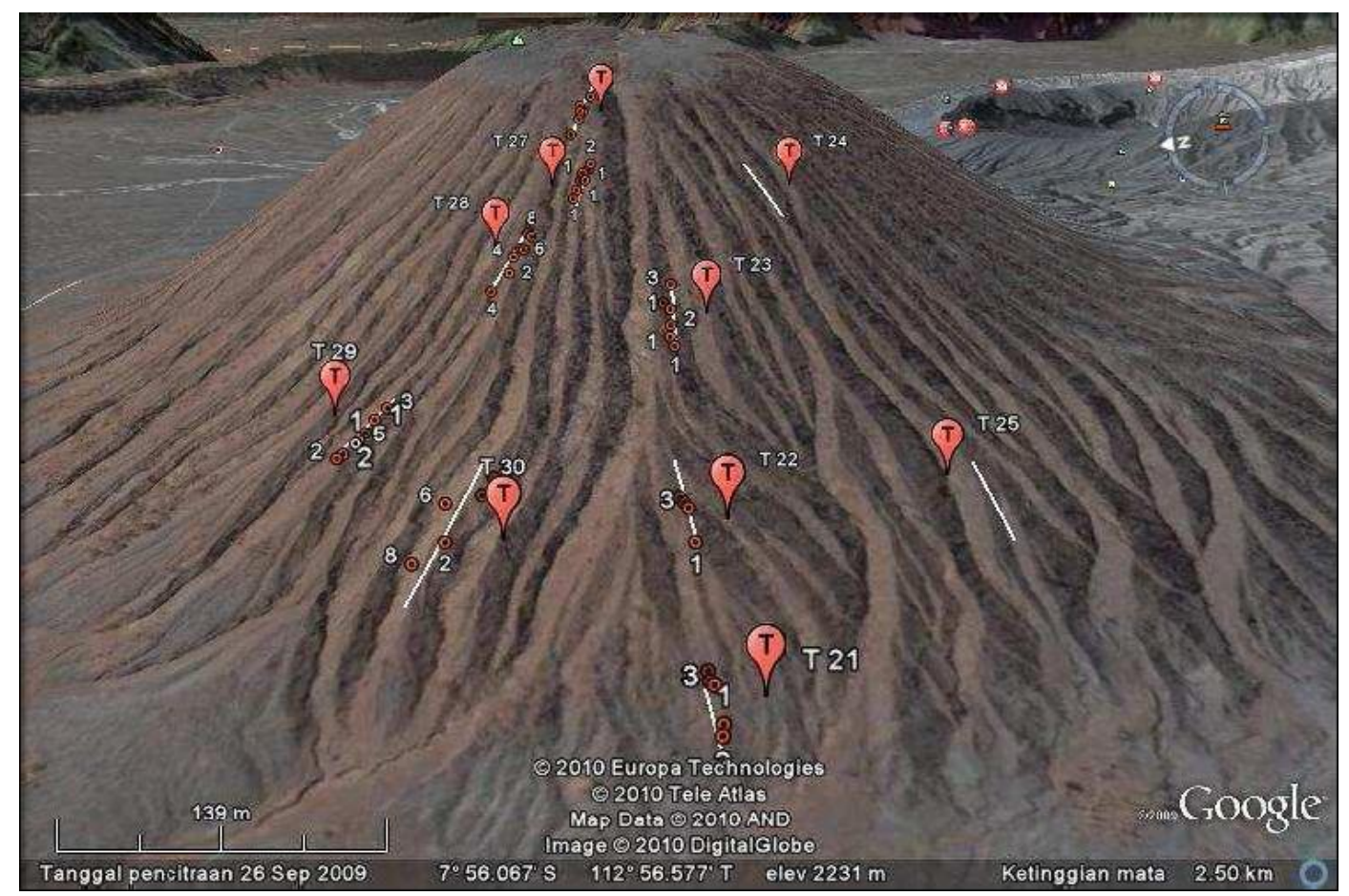

Gambar 4.5 Letak edelweis (A. javanica) di Gunung Batok bagian Barat (Google earth, 2010

Kerapatan edelweis di bagian Timur adalah 56,25 edelweis/ha. Edelweis (A. javanica) yang ada di bagian Timur banyak ditemukan di daerah Timur Laut yaitu pada transek 31 sampai transek 35. Pada bagian Timur edelweis sedikit sekali ditemukan disebabkan karena ada beberapa daerah di bagian Timur Gunung Batok yang berbatasan langsung dengan Gunung Bromo, sehingga ada beberapa tempat di bagian Timur yang kering tanpa adanya tumbuhan sama sekali.

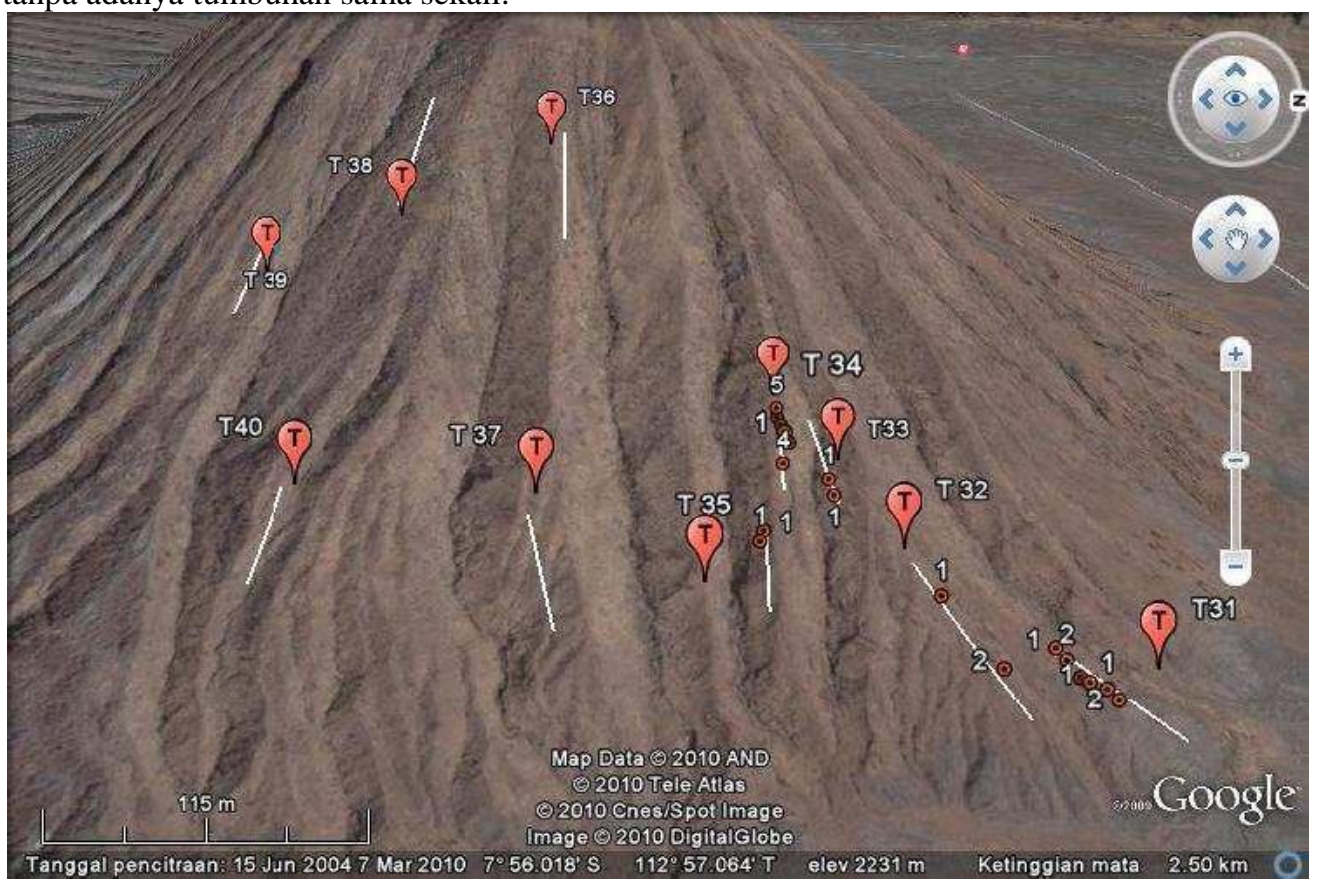

Gambar 4.7 Letak edelweis (A. javanica) di Gunung Batok bagian Timur (Google earth, 2010

Kerapatan total dari edelweis (A. javanica) di Gunung Batok adalah 936,25 edelweis/ha. Bila dilihat dari kriteria IUCN dalam Mogea et al. (2001) maka edelweis (A. javanica) di Gunung Batok belum termasuk dalam katagori, kritis, rawan maupun genting. Hal ini disebabkan karena jumlah individu dewasa per ha. masih lebih tinggi dari pada ketentuan yang dipakai oleh IUCN

\section{Distribusi Edelweis (A. javanica)}


Berdasarkan perhitungan dengan menggunakan Indeks Morisita (lampiran 2) Pola penyebaran edelweis (A. javanica) di Gunung Batok adalah mengelompok dan setelah diuji lanjut dengan analisis Chi-squere pola distribusi edelweis (A. javanica) di Gunung Batok adalah seragam. Edelweis (A. javanica) mempunyai distribusi mengelompok dikarenakan tumbuhan ini bereproduksi dengan biji yangjatuh disekitar tempat hidupnya, sehingga anakan yang tumbuh tidak jauh dari induknya.

Edelweis di gunung Batok cenderung tumbuh mengelompok di daerah terbuka dan di lereng-lereng gunung batok. Hasil tersebut, terlepas dari pengaruh faktor lingkungan dan kompetisi, relevan dengan kesimpulan Barbour et al (1987) dalam Djufri (2002) bahwa pola distribusi spesies tumbuhan cenderung

mengelompok, sebab tumbuhan bereproduksi dengan biji yang jatuh dekat induknya atau dengan rimpang yang menghasilkan anakan vegetatif masih dekat dengan induknya.

Bila faktor yang mempengaruhi kehadiran spesies pada suatu tempat relatif kecil, maka ini merupakan kesempatan semata dan biasanya menghasilkan pola distribusi spesies secara acak (Greig-Smith, 1983) dalam Djufri (2002). Hasil perhitungan pola distribusi edelweis (A. javanica) di Gunung Batok menunjukkan kenyataan yang berbeda, karena sebagian besar menunjukkan pola distribusi mengelompok. Dengan demikian, tentu ada faktor lain yang lebih berpengaruh tetapi bukan faktor kecepatan angin, kelembaban dan suhu yang diukur dalam penelitian ini. Gejala ini mungkin dapat dipelajari melalui penelitian lebih lanjut melalui pengukuran parameter lingkungan lain, dan mengamati pengaruh kompetisi terhadap kehadiran spesies.

\section{Faktor Abiotik}

Setiap spesies tumbuhan, memerlukan kondisi lingkungan yang sesuai untuk hidup, sehingga persyaratan hidup setiap spesies berbeda-beda, dimana mereka hanya menempati bagian yang cocok bagi kehidupannya. Barbour et al, (1987) dalam Djufri (2002) menyimpulkan setiap tumbuhan merupakan hasil dari kondisi tempat dimana tumbuhan itu hidup, sehingga tumbuhan dapat dijadikan sebagai indikator lingkungan. Menurut Ewusie (1990), cahaya, temperatur dan air secara ekologis merupakan faktor lingkungan yang penting. Selanjutnya Suin (2002), menjelaskan faktor lingkungan abiotik sangat menentukan penyebaran dan pertumbuhan suatu organisme dan tiap jenis hanya dapat hidup pada kondisi abiotik tertentu yangberada dalam kisaran toleransi tertentu yang cocok bagi organisme tersebut.

Berdasarkan analisis regresi ganda menunjukkan bahwa faktor abiotik yang ditentukan pada penelitian ini mempunyai pengaruh yang relatif kecil terhadap jumlah edelweis (A. javanica). Hal ini disebabkan karena sedikitnya perbedaan ketinggian tempat dari permukaan laut sehingga antara bagian Utara, Selatan, Timur dan Barat mempunyai suhu, kelembaban dan kecepatan angin yang relatif sama.

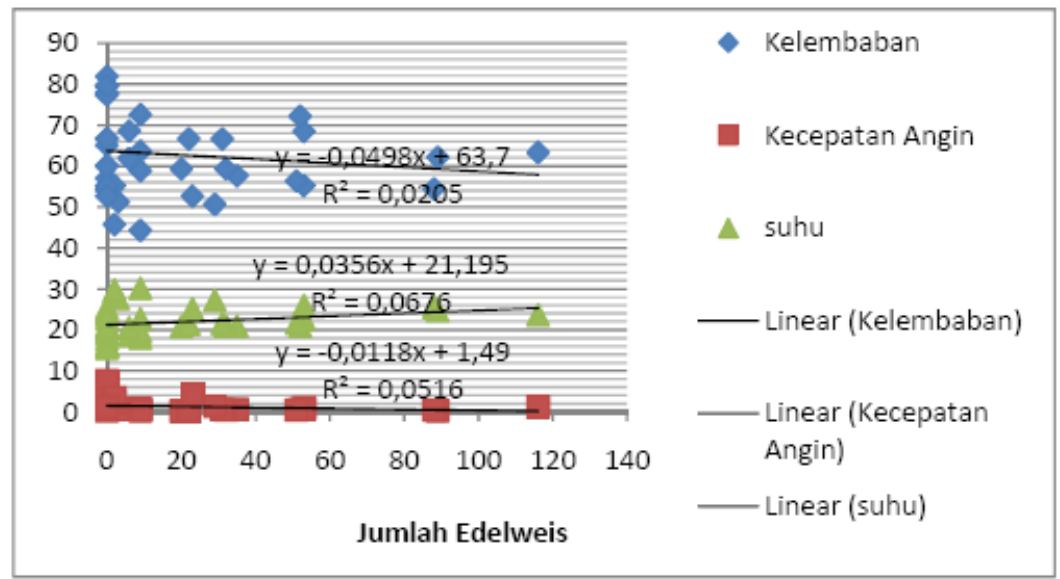

Gambar 4.8 Grafik regresi linier kelembaban, suhu, dan kecepatan angin terhadap jumlah edelweis

Menurut Ewusie (1990), faktor iklim antara lain suhu udara, sinar matahari, kelembaban udara dan angin sangat berpengaruh terhadap proses pertumbuhan tanaman. Ketinggian tempat adalah ketinggian dari permukaan air laut (elevasi). Ketinggian tempat mempengaruhi perubahan suhu udara. Semakin tinggi suatu tempat, misalnya pegunungan, semakin rendah suhu udaranya atau udaranya semakin dingin. Semakin rendah daerahnya semakin tinggi suhu udaranya atau udaranya semakin panas. Oleh karena itu ketinggian suatu tempat berpengaruh terhadap suhu suatu wilayah.

Bila faktor yang mempengaruhi kehadiran spesies pada suatu tempat relatif kecil, maka ini merupakan kesempatan semata dan biasanya menghasilkan pola distribusi spesies secara acak (Greig-Smith, 1983) dalam Djufri (2002). Hasil perhitungan pola distribusi edelweis (A. javanica) di Gunung Batok menunjukkan kenyataan yang berbeda, karena sebagian besar menunjukkan pola distribusi mengelompok. Dengan demikian, tentu ada faktor lain yang lebih berpengaruh tetapi bukan faktor kecepatan angin, kelembaban dan suhu yang diukur dalam penelitian ini. Gejala ini mungkin dapat dipelajari melalui penelitian lebih lanjut melalui pengukuran parameter lingkungan lain, dan mengamati pengaruh kompetisi terhadap kehadiran spesies. 


\section{Kesimpulan}

Berdasarkan hasil pengamatan dan pembahasan pada bab sebelumnya, dapat diambil kesimpulan sebagai berikut:

1. Kerapatan Edelweis (A. javanica) di Gunung Batok adalah 936,25 edelweis/ha. Bila dilihat dari kriteria IUCN, maka edelweis (A. javanica) di Gunung Batok belum masuk dalam katagori kritis, rawan maupun genting.

2. Pola penyebaran edelweis (A. javanica) di Gunung Batok Taman Nasional Bromo tengger Semeru, berdasarkan analisis indeks penyebaran morisita adalah mengelompok seragam. 